\section{Postbloom Humic- and Fulvic-based Zinc Sprays Can Improve Apple Zinc Nutrition}

\author{
G.H. Neilsen, E.J. Hogue, D. Neilsen, and P. Bowen \\ Agriculture and Agri-Food Canada, Pacific Agri-Food Research Centre, \\ Summerland, B.C. VOH 1Z0, Canada
}

Additional index words. leaf and fruit $\mathrm{Zn}$, Malus $\times$ domestica, yield

\begin{abstract}
Zinc supplied as a fulvic-based Zn compound was absorbed and retranslocated to unsprayed new growth as effectively as zinc sulphate in apple seedlings of low Zn status grown hydroponically in the greenhouse. Similarly, fulvic- and humic-based compounds were as effective as zinc sulphate at improving short-term growth and $\mathrm{Zn}$ uptake into new tissues in Zn-deficient apple seedlings, with the best growth occurring at spray concentrations of $\mathrm{Zn}$ at $500 \mathrm{mg} \cdot \mathrm{L}^{-1}$. Under field conditions, $\mathrm{Zn}$ concentration of peeled and washed 'Jonagold' apples at harvest was increased, without phytotoxicity, by two or four postbloom sprays of fulvic $\mathrm{Zn}$. It is therefore possible to use this material safely as an effective $\mathrm{Zn}$-source after bloom. However the mobility of the foliar-applied $\mathrm{Zn}$ is limited and any yield response by treated apple orchards of marginal $\mathrm{Zn}$ nutrition is unlikely to occur in the short term (within two growing seasons).
\end{abstract}

Zinc deficiency in apples has long been recognized in the semi-arid, fruit production regions of the Pacific Northwest region of North America (Chandler et al, 1932; Woodbridge, 1954) and the general importance of zinc for horticultural crop production has recently been reviewed (Swietlik, 1999). As a consequence, dormant $\mathrm{Zn}$ sprays are frequently applied to apple trees in British Columbia and Washington State although it has been recognized that annual dormant $\mathrm{Zn}$ sprays have been unable to prevent the decline in leaf $\mathrm{Zn}$ concentration in May to values near or below the commonly accepted deficiency concentration by midsummer (Neilsen, 1988). This has stimulated interest in application of $\mathrm{Zn}$ at different times of the year (Neilsen and Hoyt, 1990). Soluble zinc sulphate, which has a high $\mathrm{Zn}$ concentration, has been commonly applied as a dormant spray but unfortunately can result in severe russetting and cracking of fruit when applied immediately postbloom to fruiting trees (Neilsen and Neilsen, 2002).

Other zinc-containing compounds, such as zinc chelates, have been reported to have low phytotoxicity and have been assessed as to their suitability to correct conditions of inadequate Zn (Neilsen and Hogue, 1983) although their postharvest application has been shown to be ineffective (Benson et al., 1957). It would be desirable to assess the suitability and effectiveness of $\mathrm{Zn}$ compounds to supply $\mathrm{Zn}$ safely soon after bloom when simultaneous growth and high nutrient demand occurs for developing shoots, fruits and roots. Recently, fulvic and humic acid compounds containing $\mathrm{Zn}$ have been advocated for use at this post-

Received for publication 25 May 2004. Accepted for publication 8 Aug. 2004 We acknowledge the technical assistance of B. Rabie and L. Herbert. Financial support was provided by Black Earth Humates Ltd., Edmonton, Alberta and Agriculture and Agri-Food Canada's Matching Investment Initiative Program. bloom time with little information to support their use. Thus, several greenhouse trials and a field trial were undertaken in order to assess the effectiveness of humic- and fulvic- $\mathrm{Zn}$ compounds to increase tissue $\mathrm{Zn}$ uptake and modify growth performance of apple with marginal to inadequate $\mathrm{Zn}$ status.

\section{Materials and Methods}

Greenhouse trials. Open-pollinated 'McIntosh' seeds, stratified at 2 to $4{ }^{\circ} \mathrm{C}$ for 12 weeks in moist paper towels, were germinated in flats containing a sterile 2 vermiculite : 1 perlite mixture. At the three-leaf stage ( 2 to 3 weeks), seedlings were transplanted and grown individually in 1-L plastic bags within black containers topped with plywood and containing Long Ashton nutrient solution minus $\mathrm{Zn}$ (Hewitt, 1966). Seedlings , fastened to wooden supports, were grown in the greenhouse under 16-h day-length conditions for either 8 weeks (Expt. 1) or 4 weeks (Expt. 2). Supplemental light (400 to $700 \mathrm{~nm}$ ) was provided by 400 W high-pressure sodium lights. Greenhouse temperatures ranged from $18 \pm 1^{\circ} \mathrm{C}$ (night) to $24 \pm 2{ }^{\circ} \mathrm{C}$ (day). Nutrient solutions were replenished frequently and routine chemical sprays applied where appropriate to control insects and diseases. Continuous aeration was provided by bubbling air through each container via a manifold constructed of irrigation tubing and connected to a compressor.

For Expt. 1, seedlings grown from $17 \mathrm{Aug}$. 2000 to 18 Sept. 2000 in minus-Zn solution were used as a source of uniform low-Zn seedlings. On 18 Sept., 10 replicate seedlings per treatment were removed from solution and treated as follows: 1) unsprayed (control); 2) sprayed with $\mathrm{Zn}$ at 1000 or 3) $\mathrm{Zn}$ at 5000 $\mathrm{mg} \cdot \mathrm{L}^{-1}$ as $\mathrm{L}-133$ fulvic $\mathrm{Zn}$ product $(14 \%$ w/w Zn, pH 1.7, Black Earth Humates Ltd., Edmonton, Alberta); 4) sprayed with $\mathrm{Zn}$ at 1000 or 5) $\mathrm{Zn}$ at $5000 \mathrm{mg} \cdot \mathrm{L}^{-1}$ as zinc sulphate
(36\% w/w Zn); 6) sprayed with $5000 \mathrm{mg} \cdot \mathrm{L}^{-1}$ as zinc sulphate or 7) as fulvic $\mathrm{Zn}$ (L-133) both containing $0.25 \%$ (v/v) Sylgard 309, a siloxylated polyether $76 \%$ nonionic surfactant (Dow Corning, Midland, Mich.). The organic Zn products (e.g., L-133) used in the various experiments are experimental formulations not yet priced for general sale. Current information can be obtained from Black Earth Humates Ltd. (www.luscarspecialtyproducts.com) Seedling tops were sprayed to near runoff with a fine mist in a manner to avoid subsequent contamination since seedlings were returned to the minus $\mathrm{Zn}$ solution to continue growth until harvest. A twist tie marked the last leaves sprayed. At harvest on 23 Nov. 2000 the top $10 \mathrm{~cm}$ of shoot growth (above the sprayed leaves) was removed to determine fresh weight and $\mathrm{Zn}$ concentration and content for each replicate of each treatment. Tissue $\mathrm{Zn}$ concentration was determined after oven-drying overnight at $65^{\circ} \mathrm{C}$, grinding, weighing and ashing at 475 ${ }^{\circ} \mathrm{C}$ for $3 \mathrm{~h}$. Ash was dissolved in $0.5 \mathrm{M} \mathrm{HCl}$ before $\mathrm{Zn}$ determination by atomic absorption spectrophotometry. Absolute Zn uptake per shoot tip was determined as the product of $\mathrm{Zn}$ concentration and tip dry weight.

For Expt. 2, apple seedlings were grown 1 Nov. to 4 Dec. 2000 in minus-Zn Long Ashton solution in a similar manner to Expt. 1 to produce a uniform batch of low $\mathrm{Zn}$ to Zn-deficient seedlings. Similarly 10 replicate seedlings were sprayed on 4 Dec. 2000 with 1) distilled water (no Zn control); 2) $\mathrm{Zn}$ at 500, 3) 2000 , or 4) $4000 \mathrm{mg} \cdot \mathrm{L}^{-1}$ of L-133 fulvic Zn product; 5) Zn at 500, 6) 2000, or 7) 4000 $\mathrm{mg} \cdot \mathrm{L}^{-1}$ as L-132 humic Zn product $(9 \% \mathrm{w} / \mathrm{w}$ $\mathrm{Zn}, \mathrm{pH} 5.5,2 \% \mathrm{w} / \mathrm{v}$ humic material, also Black Earth Humates Ltd. Edmonton, Alberta); and 8) $\mathrm{Zn}$ at $2000 \mathrm{mg} \cdot \mathrm{L}^{-1}$ as zinc sulphate. All spray materials were applied with $0.25 \%$ by volume Sylgard surfactant and the plants were returned to minus-Zn solution to continue growing until harvest. At harvest, on 5 Jan. 2001, growth was separated into that which had occurred below and above the point of spray. Shoot length and number of leaves below the point of spray were measured and number of leaves, shoot length and top fresh weight of shoot plus leaves measured for growth which had occurred after spraying for each replicate of each treatment. $\mathrm{Zn}$ concentration of unsprayed leaves was also determined as previously described.

Field trial. To assess the effectiveness of the fulvic-based Zn material (L-133) under field conditions, an experiment was established in a 'Jonagold'/M.9 apple (Malus $\times$ domestica Borkh.) block planted in 1993 at $1 \mathrm{~m}$ spacing within rows separated by $3 \mathrm{~m}$. Before and during the experiment the block was maintained according to standard commercial production practices with respect to insect and disease control, pruning, irrigation and $\mathrm{N}$-fertilization (British Columbia Ministry of Agriculture and Food, 1998). Before establishment of the zinc experiment, standard industry practices involving periodic applications of zinc sulphate during late dormancy were followed. Commencing in 2001 and again in 2002, six foliar treatments were applied in a randomized complete block design with six replicate 
four-tree plots. Sprays were applied to runoff at a constant $\mathrm{Zn}$ concentration of $500 \mathrm{mg} \cdot \mathrm{L}^{-1}$. Treatments included 1) an unsprayed control; 2) a single prebloom spray of L-133 applied at tight cluster (26 Apr. 2001, 24 Apr. 2002); 3) two weekly postbloom sprays of L-133 commencing immediately after petal fall (25 and 31 May 2001; 27 May and 3 June 2002); 4) four weekly postbloom sprays of L-133 commencing immediately after petal fall (about weekly 25 May to 14 June 2001; similarly 27 May to 17 June 2002); 5) one prebloom and four postbloom L-133 sprays at dates previously indicated; and 6) the same spray regime as for L-133 in Treatment 5 but using L-132 materials. Spray drift was minimized by directed application by backpack sprayer, under calm conditions early in the morning. In 2001, application rates were about 500 $\mathrm{L} \cdot \mathrm{ha}^{-1}$ for prebloom sprays and from 660 to $700 \mathrm{~L} \cdot \mathrm{ha}^{-1}$ for postbloom sprays. Prebloom sprays were applied at $310 \mathrm{~L} \cdot \mathrm{ha}^{-1}$ and postbloom sprays at rates ranging from 900 to $1000 \mathrm{~L} \cdot \mathrm{ha}^{-1}$ in 2002.

Each time postbloom sprays were applied the same five branches per experimental plot were bagged to avoid spray contamination. The bags were removed each time immediately after the sprays had dried. Composite leaf samples were collected midsummer from all plots on 30 July 2001 and 25 July 2002. For treatments not receiving postbloom $\mathrm{Zn}$ sprays (Treatments 1 and 2), a 40-leaf sample of midterminal, new-year extension shoot leaves was randomly collected from all plot trees of each replicate. For Treatments 3 to 6 , which received postbloom $\mathrm{Zn}$ sprays, 10 midterminal, new year extension shoot leaves were collected from unsprayed (previously bagged) leaves. These leaves were subsequently analysed for $\mathrm{Zn}$ as previously described. In 2002 average weight and leaf area of sampled leaves was measured to express $\mathrm{Zn}$ uptake per unit leaf area.

At commercial harvest each year (3 Oct. 2001; 12 Oct. 2002) a random 30-fruit sample was collected from each treatment and replicate. Fruit remaining for each treatment and replication were counted and weighed. Average fruit weight for all plots was then calculated by dividing total harvest weight by total fruit number. The random fruit samples were rinsed under running distilled water and then air-dried. Fruit were peeled, stem tissue and seeds were removed and opposite quarters were blended with 1.5 times their weight of distilled water. A 150-mL subsample was further homogenized with a high-speed tissue homogenizer. A weighed 9-mL subsample of homogenized slurry was digested in $5.4 \mathrm{~mL}$ of concentrated $\mathrm{H}_{2} \mathrm{SO}_{4}$ containing $\mathrm{Na}_{2} \mathrm{SO}_{4}(18$ $\mathrm{g}), \mathrm{Cu}\left(0.36 \mathrm{~mL} 25 \% \mathrm{CuSO}_{4}\right.$ solution), and $\mathrm{Se}$ $\left(0.67 \mathrm{~g} \cdot \mathrm{L}^{-1}\right)$ at $380{ }^{\circ} \mathrm{C}$ for $1 \mathrm{~h}$. $\mathrm{Zn}$ was determined in these extracts via atomic absorption spectrophotometry.

All trials. Analysis of variance (ANOVA) was performed on all growth, yield and $\mathrm{Zn}$ content data according to the experimental design (SAS Institute Inc., 1989). In Expt. 1, individual df analyses were performed to detect linear and quadratic responses to applied $\mathrm{Zn}$ levels, the effects of $\mathrm{Zn}$ form (L-133 vs zinc sulphate), the effects of Sylgard surfactant and the interaction between $\mathrm{Zn}$-form and the surfactant (Table 1). In Expt. 2, individual df analyses were used to determine the effects of foliar Zn application; comparing L-133 and $\mathrm{L}-132$ to $\mathrm{ZnSO}_{4}$ at equal $\mathrm{Zn}$ concentrations (2000 mg. $\mathrm{L}^{-1}$ ); comparing effects of L-133 to L-132 over a range of $\mathrm{Zn}$ concentrations; and determining the linear and quadratic effects of $\mathrm{Zn}$ concentration for both L-133 and L-132 (Table 2). In Expt. 3, individual df analyses determined the effects of foliar $\mathrm{Zn}$ amendment; compared prebloom to postbloom application of L-133; compared L-133 to L-132 form; and compared the effects of two or four postbloom sprays of L-133 (Table 3).

\section{Results and Discussions}

Greenhouse experiment 1. Fresh mass of the top $10 \mathrm{~cm}$ of shoots produced above sprayed leaves after spray application was unaffected by Zn application (data not shown). Both concentration and absolute uptake of $\mathrm{Zn}$ in the growing tip was however significantly affected by spray treatment (Table 1). There was a linear increase in $\mathrm{Zn}$ concentration and uptake, regardless of $\mathrm{Zn}$ form, as concentration of spray solution increased from 0 to
$5000 \mathrm{mg} \cdot \mathrm{L}^{-1}$. Chemical formulation of the Zn spray significantly affected Zn nutrition with leaf $\mathrm{Zn}$ concentrations and uptake higher for seedlings sprayed with L-133 rather than zinc sulphate at both spray concentrations. The Sylgard adjuvant significantly increased leaf $\mathrm{Zn}$ concentration and $\mathrm{Zn}$ uptake for the $5000 \mathrm{mg} \cdot \mathrm{L}^{-1}$ zinc sulphate but not the L-133 spray treatment.

The lack of a growth response to $\mathrm{Zn}$ applications, general absence of Zn-deficiency symptoms and relatively high shoot tip $\mathrm{Zn}$ concentrations (24.9 $\mathrm{mg} \cdot \mathrm{kg}^{-1}$ dry weight) on minus- Zn seedlings suggest that without sprays these seedlings should be considered of low to adequate rather than severely deficient $\mathrm{Zn}$ status. The difficulties of achieving Zn deficiency for apple seedlings in nutrient solution when apple seeds have high $\mathrm{Zn}$ concentration and reagent grade chemicals contain $\mathrm{Zn}$-contaminants have previously been discussed (Neilsen and Hogue, 1986). Nevertheless results from Expt. 1 indicate effective uptake and translocation of $\mathrm{Zn}$ to growing tips after foliar applications of $\mathrm{L}-133$ relative to zinc sulphate under conditions of low $\mathrm{Zn}$ supply. This is promising due to the inability to use zinc sulphate on fruiting trees because of damage to fruit (Neilsen and Neilsen, 2002).

Table 1. Effect of various foliar $\mathrm{Zn}$ treatments on shoot tip growth, Zn concentration and uptake, Greenhouse Expt. 1, 2000.

\begin{tabular}{|c|c|c|}
\hline $\begin{array}{l}\text { Treatment } \\
\text { Zn concn } \\
\left(\mathrm{mg} \cdot \mathrm{L}^{-1}\right)\end{array}$ & $\begin{array}{c}\text { Shoot tip } \\
\text { Zn concn } \\
\left(\mu \mathrm{g} \cdot \mathrm{g}^{-1} \text { dry wt }\right)\end{array}$ & $\begin{array}{c}\text { Shoot tip } \\
\text { absolute } \\
\text { Zn uptake } \\
(\mu \mathrm{g})\end{array}$ \\
\hline 1. Control (no Zn) & 24.9 & 69.3 \\
\hline 2. L-133 (1000) & 42.7 & 129.0 \\
\hline 3. L-133 (5000) & 63.7 & 180.0 \\
\hline 4. $\mathrm{ZnSO}_{4}(1000)$ & 29.7 & 77.0 \\
\hline 5. $\mathrm{ZnSO}_{4}(5000)$ & 37.6 & 103.1 \\
\hline 6. $\mathrm{ZnSO}_{4}(5000+\operatorname{Sylgard}(0.25 \% \mathrm{v} / \mathrm{v}))$ & 56.6 & 149.7 \\
\hline 7. L-133 (5000 + Sylgard $(0.25 \%$ v/v $))$ & 46.5 & 108.2 \\
\hline Significance & $* * * *$ & $* * * *$ \\
\hline \multicolumn{3}{|l|}{ Individual df analyses } \\
\hline Linear, $\mathrm{Zn}$ & $* * * *$ & $* * * *$ \\
\hline Quadratic, Zn & NS & NS \\
\hline $\mathrm{L}-133$ vs. $\mathrm{ZnSO}_{4}$ & $* *$ & $* *$ \\
\hline Sylgard vs. no Sylgard & NS & NS \\
\hline Sylgard $\times$ form & $* * * *$ & $* * * *$ \\
\hline
\end{tabular}

NS,**,***** Individual degree of freedom contrasts nonsignificant or significant at $1 \%$ or $0.01 \%$, respectively.

Table 2. Effect of various foliar $\mathrm{Zn}$ treatments on growth of apple seedlings above the point of spray, Greenhouse Expt. 2, 2000.

\begin{tabular}{|c|c|c|c|c|}
\hline \multirow{2}{*}{$\begin{array}{l}\text { Treatment } \\
\text { Zn concn } \\
\left(\mathrm{mg} \cdot \mathrm{L}^{-1}\right)\end{array}$} & \multicolumn{4}{|c|}{ Top (above spray) } \\
\hline & $\begin{array}{l}\text { No. of } \\
\text { leaves }\end{array}$ & $\begin{array}{l}\text { Length } \\
\text { (cm) }\end{array}$ & $\begin{array}{l}\text { Fresh } \\
\text { wt (g) }\end{array}$ & $\begin{array}{l}\text { Leaf } \mathrm{Zn} \text { concn } \\
\left(\mu \mathrm{g} \cdot \mathrm{g}^{-1} \text { dry wt) }\right.\end{array}$ \\
\hline 1. Control-no Zn & 11.7 & 20.9 & 9.8 & 10.3 \\
\hline 2. L-133 (500) & 14.2 & 38.3 & 17.9 & 14.9 \\
\hline 3. L-133 (2000) & 14.0 & 36.1 & 15.1 & 28.0 \\
\hline 4. L-133 (4000) & 10.2 & 23.5 & 9.0 & 48.1 \\
\hline 5. L-132 (500) & 14.6 & 39.5 & 18.2 & 17.6 \\
\hline 6. L-132 (2000) & 13.0 & 33.2 & 14.2 & 30.7 \\
\hline 7. L-132 (4000) & 9.1 & 19.0 & 7.5 & 44.1 \\
\hline 8. $\mathrm{ZnSO}_{4}(2000)$ & 14.0 & 30.3 & 16.7 & 11.6 \\
\hline Significance & $* *$ & $* * * *$ & $* * * *$ & $* * * *$ \\
\hline \multicolumn{5}{|l|}{ Individual df analyses } \\
\hline Zinc & NS & $* *$ & $*$ & $* * * *$ \\
\hline $\mathrm{L}-133$ vs $\mathrm{ZnSO}_{4}$ & NS & NS & NS & $* *$ \\
\hline $\mathrm{L}-132$ vs $\mathrm{ZnSO}_{4}$ & NS & NS & NS & $* *$ \\
\hline L-132 vs L-133 & NS & NS & NS & NS \\
\hline Linear both & $* * * *$ & $* * * *$ & $* * * *$ & $* * * *$ \\
\hline Quadratic both & NS & NS & NS & NS \\
\hline
\end{tabular}




\begin{tabular}{|c|c|c|c|c|c|}
\hline \multirow{2}{*}{$\begin{array}{l}\text { Treatment }{ }^{\mathrm{z}} / \\
\text { timing }\end{array}$} & \multicolumn{2}{|c|}{$\begin{array}{c}\text { Leaf Zn } \\
\left(\mu \mathrm{g} \cdot \mathrm{g}^{-1} \text { dry wt }\right)\end{array}$} & \multirow{2}{*}{$\begin{array}{c}\begin{array}{c}\text { Zn uptake } \\
\text { per leaf area } \\
\left(\mu \mathrm{g} \cdot \mathrm{cm}^{-2}\right)\end{array} \\
2002\end{array}$} & \multicolumn{2}{|c|}{$\begin{array}{c}\text { Fruit Zn } \\
(\mathrm{mg} / 100 \mathrm{~g} \text { fresh wt) }\end{array}$} \\
\hline & 2001 & 2002 & & 2001 & 2002 \\
\hline 1. Check-no Zn & 12.3 & 11.3 & 0.15 & 0.011 & 0.009 \\
\hline 2. Prebloom L-133-once at tighcluster & 12.9 & 12.4 & 0.14 & 0.013 & 0.009 \\
\hline 3. Postbloom L-133 twice weekly after petal fall & 13.2 & 13.7 & 0.18 & 0.017 & 0.013 \\
\hline 4. Postbloom L-133 four weekly sprays after petal fall & 10.9 & 13.1 & 0.17 & 0.019 & 0.017 \\
\hline 5. Prebloom + Postbloom L-133 (Treatments $2+4)$ & 13.4 & 14.9 & 0.19 & 0.024 & 0.019 \\
\hline 6. Prebloom + postbloom L-132 (as Treatment 5 with L-132) & 13.3 & 14.0 & 0.18 & 0.026 & 0.017 \\
\hline Significance & NS & NS & $*$ & $* * * *$ & $* * * *$ \\
\hline \multicolumn{6}{|l|}{ Individual df analyses } \\
\hline Zinc & NS & $*$ & $*$ & $* * *$ & $* * * *$ \\
\hline Prebloom vs. postbloom & NS & NS & $*$ & $*$ & $* * * *$ \\
\hline L-133 vs. L-132 & NS & NS & NS & NS & $*$ \\
\hline Number of postbloom sprays & NS & NS & NS & NS & $* * * *$ \\
\hline
\end{tabular}

${ }^{\mathrm{z}} \mathrm{All} \mathrm{Zn}$ sprays applied at a Zn concentration of $500 \mathrm{mg} \cdot \mathrm{L}^{-1}$ with Sylgard $(0.25 \% \mathrm{v} / \mathrm{v})$.

NS,,$* * * * * * *$ Individual degree of freedom contrasts nonsignificant or significant at $5 \%, 0.1 \%$, or $0.01 \%$, respectively.

Greenhouse experiment 2. In a second greenhouse experiment, growth responses were generally observed after foliar application of Zn compounds to seedlings grown for 4 weeks in minus-Zn Long Ashton solution. Before foliar spray application of $\mathrm{Zn}$ there were few differences in growth among treatments, as indicated by shoot length or number of leaves (data not shown). Following differential spray treatments, top fresh weight and shoot length but not number of leaves above the point of spray application of zinc were increased after four weeks of continuing growth (Table 2). Concentration of $\mathrm{Zn}$ in sprays of both L-133 and L-132 inversely affected all three growth parameters with superior growth observed at low $\mathrm{Zn}$ concentration of spray solution. Growth was least at $4000 \mathrm{mg} \cdot \mathrm{L}^{-1}$, the highest spray solution concentration. There were no differences in growth among seedlings treated with L-133, L-132 or zinc sulphate compounds when compared at a $\mathrm{Zn}$ application concentration of $2000 \mathrm{mg} \cdot \mathrm{L}^{-1}$. When concentration of zinc in leaves which grew after application of $\mathrm{Zn}$ was measured, Zn-treatments generally augmented leaf Zn. Both L-133 and L-132 were equally effective and created higher leaf Zn concentrations than did zinc sulphate. In contrast to observations regarding growth, leaf $\mathrm{Zn}$ concentration linearly increased in direct proportion to $\mathrm{Zn}$ concentration of spray solutions.

Improved growth of apple seedlings after application of foliar-Zn sprays implies the seedlings were $\mathrm{Zn}$ deficient. Consistent with this assessment is a leaf $\mathrm{Zn}$ concentration averaging $10.3 \mathrm{mg} \cdot \mathrm{kg}^{-1}$ for unsprayed control plants, which is less than the $14 \mathrm{mg} \cdot \mathrm{kg}^{-1}$ deficiency threshold for apple (Shear and Faust, 1980). The low leaf $\mathrm{Zn}$ content of seedlings sprayed with zinc sulphate relative to that of unsprayed seedlings indicates that zinc concentration without associated growth measures is not a definitive measure of plant response to foliar Zn application (Neilsen and Hogue, 1983). Nevertheless the results of Expt. 2 indicate that both L-133 and L-132 are as effective as zinc sulphate in improving growth of $\mathrm{Zn}$-deficient seedlings. Both materials were superior to zinc sulphate in their effectiveness in translocating Zn from sprayed to actively growing, unsprayed leaves. The higher leaf $\mathrm{Zn}$ concentration after application of $\mathrm{Zn}$ sprays of $4000 \mathrm{mg} \cdot \mathrm{L}^{-1}$ was associated with reduced growth resulting from phytotoxicity. In general these results are promising for L-133 and L-132 but these products need to be tested under field conditions on trees bearing fruit and with leaves which have a different morphology than those grown under greenhouse conditions.

Field experiment. Leaf $\mathrm{Zn}$ concentration of unsprayed leaves was unaffected by spray treatment in the first year of the field experiment and the concentration was increased by $\mathrm{Zn}$ sprays in year 2 (Table 3 ). In the second year, when the $\mathrm{Zn}$ data were expressed as amount of $\mathrm{Zn}$ per unit leaf area, leaf $\mathrm{Zn}$ content of trees receiving two or four postbloom sprays exceeded those receiving only prebloom $\mathrm{Zn}$. Fruit $\mathrm{Zn}$ concentration proved to be a sensitive indicator of treatment differences. In both years foliar application of $\mathrm{Zn}$ significantly increased fruit $\mathrm{Zn}$ concentration. Zinc concentration of fruit from trees receiving two or four postbloom sprays consistently exceeded that of trees receiving only prebloom $\mathrm{Zn}$. Only in the second year of the trial were there differences in performance between $\mathrm{Zn}$ formulations, with fruit $\mathrm{Zn}$ concentrations higher for trees receiving multiple applications of $\mathrm{L}-133$ rather than L-132 zinc. Also in the second year $\mathrm{Zn}$ concentration of fruit receiving four postbloom sprays exceeded that of fruit receiving only two postbloom sprays. There were no differences in per tree cumulative yield $(\mathrm{kg})$, fruit number or average fruit weight $(\mathrm{g})$ among treatments over the 2-year field study (data not shown).

Before the establishment of the experiment, Zn-deficiency symptoms including little leaf, rosetting and leaf chlorosis had been observed in some years on some trees throughout the experimental block. On average, leaf $\mathrm{Zn}$ concentrations of 11 to $12 \mathrm{mg} \cdot \mathrm{kg}^{-1}$ for unsprayed (check) trees were in a range considered to be Zn deficient (Shear and Faust, 1980). It was possible to safely apply both experimental compounds (L-133, L-132) with $\mathrm{Zn}$ at 500 $\mathrm{mg} \cdot \mathrm{L}^{-1}$ without phytotoxic damage to young fruit on the trees. This contrasts to severe apple fruitlet damage observed after application of two to four postbloom zinc sulphate sprays applied with $\mathrm{Zn}$ at $1400 \mathrm{mg} \cdot \mathrm{L}^{-1}$ (Neilsen and Neilsen, 2002).
It was difficult to judge the effectiveness of the spray treatments based on improvements in the $\mathrm{Zn}$ concentration of midterminal, new year's leaves on unsprayed shoots since few differences were observed in leaf $\mathrm{Zn}$ concentration among treatments. Only in the second year did foliar Zn sprays significantly increase leaf $\mathrm{Zn}$ concentration and was higher absolute uptake of $\mathrm{Zn}$ measurable for trees receiving postbloom relative to prebloom sprays. In contrast, $\mathrm{Zn}$ concentration of washed and peeled apples at commercial harvest readily reflected the effects of early-season $\mathrm{Zn}$ sprays. In both years, foliar $\mathrm{Zn}$ sprays increased fruit $\mathrm{Zn}$ concentration and treatments involving postbloom $\mathrm{Zn}$ sprays were more effective in increasing fruit $\mathrm{Zn}$ than prebloom $\mathrm{Zn}$. In the second year, multiple L-133 sprays were more effective than the same number of L-132 sprays. Also in year 2, four postbloom sprays resulted in higher fruit $\mathrm{Zn}$ than two postbloom sprays. Together the leaf and fruit $\mathrm{Zn}$ concentration responses suggest a limited translocation of $\mathrm{Zn}$ from point of application. It would further appear that multiple sprays are more effective at increasing the $\mathrm{Zn}$ status of low- $\mathrm{Zn}$ tissue. Fruit $Z n$ concentrations in this experiment were very low relative to values from other regions but typical of values in the Pacific Northwest of North America. For example, the highest fruit $\mathrm{Zn}$ concentrations measured in the 2 years of the study (Treatment 6, year 2000) were less than fruit $\mathrm{Zn}$ concentrations for trees receiving no supplemental Zn in England (Johnson and Dover, 2002).

Although fruit $\mathrm{Zn}$ concentration could be effectively increased by these organicallycomplexed $\mathrm{Zn}$ materials, no significant yield response to $\mathrm{Zn}$ treatments was measured over the 2-year field trial. In part this may reflect inconsistent yield response of apple to $\mathrm{Zn}$ application unless zinc deficiency is severe (Swietlik, 1999) but this may also indicate the difficulty of demonstrating ameliorative response to a nutrient deficiency which can be sporadic in occurrence both within trees and orchard blocks (Neilsen and Neilsen, 2003). It was noteworthy however that for yield and its components fruit size and number, lowest values were consistently observed for the unsprayed control treatment implying the detrimental ef- 
fects of withholding $\mathrm{Zn}$ applications may only become apparent in the long term.

\section{Conclusions}

A single foliar spray of organic-based $\mathrm{Zn}$ compounds (L-133 or L-132) was equally or more effective than zinc sulphate at being absorbed by vegetative apple seedling tissue and being retranslocated into new growth for plants grown hydroponically in the greenhouse. When seedlings were Zn-deficient, spraying Zn sufficed to stimulate plant growth in the short term. When spray solution $\mathrm{Zn}$ concentrations were as high as $4,000 \mathrm{mg} \cdot \mathrm{L}^{-1}$ plant growth but not tissue $\mathrm{Zn}$ concentration was suppressed. Multiple pre and postbloom sprays of L-133 or L-132 were not phytotoxic and were effective under field conditions at increasing $\mathrm{Zn}$ concentration of peeled and washed fruit at harvest. Effects were less dramatic for bagged shoot leaves, although by the second year $\mathrm{Zn}$ concentration and absolute $\mathrm{Zn}$ uptake was increased (relative to unsprayed trees) by a prebloom and four weekly sprays of L-133 after petal fall. Since it is not possible to apply zinc sulphate without phytotoxicity during this early season period, L-133 and L-132 Zn products can be used by apple growers in chronically $\mathrm{Zn}$ deficient regions to supplement tree $\mathrm{Zn}$ needs. It is likely however that augmentation of yield over a whole orchard would only be measurable over several years for trees marginally rather than severely Zn deficient.

\section{Literature Cited}

British Columbia Ministry of Agriculture and Food. 1998. Tree fruit production guide for commercial growers. Interior districts 1998-99 ed. B.C. Min. Agr. Food, Victoria, B.C.

Benson, N.R., L.P. Batjer, and I. Chmelir. 1957. Response of some deciduous fruit trees to zinc chelates. Soil Sci. 84:63-75.

Chandler, W.H., D.R. Hoagland, and P.L. Hibbard. 1932. Little leaf or rosette of fruit trees. II. Proc. Amer. Soc. Hort. Sci. 29:255-263.

Hewitt, E.J. 1966. Sand and water culture methods used in the study of plant nutrition. Commonwlth. Bur. Hort. Plantation Crops (East Malling, Maidstone, Kent, U.K.) Tech. Comm. 22.

Johnson, D.S. and C.J. Dover. 2002. The effect of calcium and zinc sprays on the texture of 'Cox's Orange Pippin' apples in controlled atmosphere storage. Acta Hort. 594:427-433.

Neilsen, G.H. 1988. Seasonal variation in leaf zinc concentration of apples receiving dormant zinc. HortScience 23:130-132.
Neilsen, G.H. and E.J. Hogue. 1983. Foliar application of chelated and mineral zinc sulphate to Zn-deficient 'McIntosh' seedlings. HortScience 18:915-917.

Neilsen, G.H. and E.J. Hogue. 1986. Some factors affecting leaf zinc concentration of apple seedlings grown in nutrient solution. HortScience 21:434-436.

Neilsen, G.H. and P.B. Hoyt. 1990. A comparison of methods to raise zinc concentration of apple leaves. Can. J. Plant Sci. 90:599-603.

Neilsen, G.H. and D. Neilsen. 2002. Effect of foliar $\mathrm{Zn}$, form and timing of $\mathrm{Ca}$ sprays on fruit $\mathrm{Ca}$ concentration in new apple cultivars. Acta Hort. 594:435-444.

Neilsen, G.H. and D. Neilsen. 2003. Nutritional requirements of apple, p. 267-302 . In: D.C. Ferree and I.J. Warrington (eds.). Apples: Botany, production and uses. CAB Intl. Publ., Oxford, U.K.

SAS. 1989. SAS/STAT. User's guide. version 6, vol. 2. SAS Inst., Cary, N.C.

Shear, C.B. and M. Faust. 1980. Nutritional ranges in deciduous tree fruits and nuts. Hort. Rev. 2:142-163.

Swietlik, D. 1999. Zinc nutrition in horticultural crops. Hort. Rev. 23:109-178.

Woodbridge, C.G. 1954.Zinc deficiency in fruit trees in the Okanagan Valley in British Columbia. Can. J. Agr. Sci. 34:545-551. 